Jpn. J. Pharm. Health Care Sci.

ノート 27(3) 255-261 (2001)

\title{
タッチパネルによる医薬品情報提供手段の構築とその評価†
}

\author{
下村一徳 ${ }^{*} \dagger^{2}$, 名德倫明 $\dagger^{2}$, 村山洋子 $\dagger^{2}$, 陶山忠士 $\dagger^{2}$, 長嶋三香子 $\dagger^{2}$, 土師久幸 $\dagger^{2}$ \\ 市立池田病院薬剤部门
}

\section{Establishment of a System to Provide Drug Information by a Touch Panel and Evaluation by the Patients $\dagger^{1}$}

\author{
Kazunori Shimomura ${ }^{*} \dagger^{2}$, Michiaki Myotoku $\dagger^{2}$, Yoko Murayama $\dagger^{2}$, \\ Tadashi Suyama $\grave{\dagger}^{2}$, Mikako Nagashima $\uparrow^{2}$ and Hisayuki Haji $\uparrow^{2}$ \\ Department of Clinical Pharmacy, Municipal Ikeda Hospital $\dagger^{2}$
}

$\left[\begin{array}{l}\text { Received September 21, } 2000 \\ \text { Accepted February 9, } 2001\end{array}\right]$

\begin{abstract}
A system that included both images and voice using a personal computer was developed to provide pharmaceutical instructions for outpatients at the medication counter. A touch panel was adopted for easy use by a wide range of age groups. The system consisted of such items as the "usage of externally applied drug", "information on disease", "patient education" and comprised eight items over all. A survey of 105 patients was conducted and almost all patients $(95 \%)$ understood the drug-related information provided. This system was found to be an effective method for providing patients with easily understood drug-related information and most patients actually enjoyed using this system which led to an improved dissemination of important medication related information.
\end{abstract}

Keywords — drug information, personal computer, phamaceutical instructions, touch panel

\section{緒言}

第 3 次医療法改定により，医療の担い手は，医療を提 供するに当たり，適切な説明を行い，医療を受ける者の 理解を得るよう努めることが義務付けられ，また薬剤師 法改定により, 医薬品の情報提供が義務付けられ, 患者 への情報提供がますます重要視されてきている。また， 情報伝達手段の発達のみならず医療を取り巻く環境の変 化もめざましいものがある．各施設も試行錯誤しながら 医薬品の適正使用の推進や薬剂管理指導業務を実施して いる.

市立池田病院は病床数 264 床, 1 日平均外来患者数 1, 354人の総合病院である. 当院ではすべての外来患者 を対象に文書による薬効, 副作用, 相互作用などの薬剤
情報提供を行い，また，投薬カウンター横に「お薬相談 コーナー」, 薬剤部内に「お薬相談室」を設け, 情報提 供の充実とより綿密な服薬指導を行っている.さらに薬 に対する関心と理解度の向上を目的として，お薬相談 コーナー横にパンフレットコーナーを設置し, 薬剤部お よびメーカー製作パンフレットや薬剤部製作小冊子など による情報提供を試みている。これらパンフレット類, 小冊子は月平均 2,000 枚以上消費され，患者の薬に対す る関心の深さが伺われ，またパンフレット類に対して患 者から質問, 問い合わせ件数が年々増加してきてい $る^{1)}$.

しかしながら，これら印刷物による情報の関心の高さ は老年層では評価が高かったが，若年層においては低い 傾向があり，また老年層では家庭に持ち帰り読む傾向が

$\dagger^{1}$ 本論文の内容の一部は, 第20回日本病院薬剤師会近畿学術大会（大阪, 1999年 1 月）で発表.

$\dagger^{2}$ 大阪府池田市城南 3-1-18; 3-1-18, Jonan, Ikeda-shi, Osaka, 563-8510 Japan 
見られたが，若年層では薬の待ち時間に読む傾向があっ た2).

今回の研究では幅広い年齢層の患者への服薬説明，患 者指導の推進を目的とし，患者の興味を引き寄せ，さら に医薬品の理解を促進する手段として，パーソナルコン ピュータを利用し，画像および音声を組み込んだプレゼ ンテーションシステム (Ikeda Audio Visual Drug Information System ; 以下, IAVDIS と略す) を構築し, その評 価を行った.

\section{方法}

\section{1. 使用機器}

使用機器の構成を Fig. 1 に示す.

1 ) ハードウェア

パソコン本体： NEC PC-9821C233

CPU : Pentium $233 \mathrm{MHz}$

メモリ：32MB

ハードディスク： $4 \mathrm{~GB}$

カラーイメージスキャナ：EPSON GT-9000

解像度 $600 \mathrm{dpi}$

デジタルカメラ：RICHO DC - 1

撮像素子 41 万画素

タッチパネル：MicroTouch CPD-205F

スピーカ：SONY SRS-D300

2) ソフトウェア

基本ソフト : Microsoft Windows 95

システムプログラム作成：

Microsoft Visual Basic

プレゼンテーション作成：

Microsoft Power Point 97

音声録音：Microsoft Sound Recoder

\section{2. システムの概要}

幅広い年齢層の利用を求め, 操作の利便性を考慮し, 画面に触れただけで動作するタッチパネルを採用し，初 期画面の各ボタンに触れることにより各項目のプレゼン テーションが開始するシステムとした.

また，初期画面のタッチ操作以外はすべて自動的に画 面変化させ, 最終的に初期画面へと戻る自動プレゼン テーション方式を採用した。

画面の表示とともに，モニタに設置したスピーカから サウンドレコーダにより録音した音声による内容説明が 始まり，視覚と聴覚を刺激するシステムとした。

情報提供内容は主に外来患者を対象としたパンフレッ ト類を基にして「医薬品の使用法」，「病態の説明」，「患 者教育」をコンセプトに 8 項目のプレゼンテーションを 作成した。

また，プレゼンテーションの所要時間は初期画面のボ タンを押した後，再び初期画面に戻るまでの時間を測定 した。

\section{IAVDIS のシステム評価}

調査時期は平成 10 年 9 月 1 日 平成 10 年 12 月 25 日の約 3 力月間とした。調査は薬剤部お薬相談空口において IAVDIS のデモンストレーションを行い, アンケート用 紙を IAVDIS 横に設置配布し，自主記入方式で回収箱に て回収する方法とした。アンケートの内容は視覚的見 解, 聴覚的見解, 操作的見解, さらに従来からのパンフ レット類との比較といった Table 1 に示す内容とした.

\section{結果}

\section{1. 情報提供システムの構築}

IAVDIS の初期画面と具体的な情報提供画面の一部を

\section{入力機器}

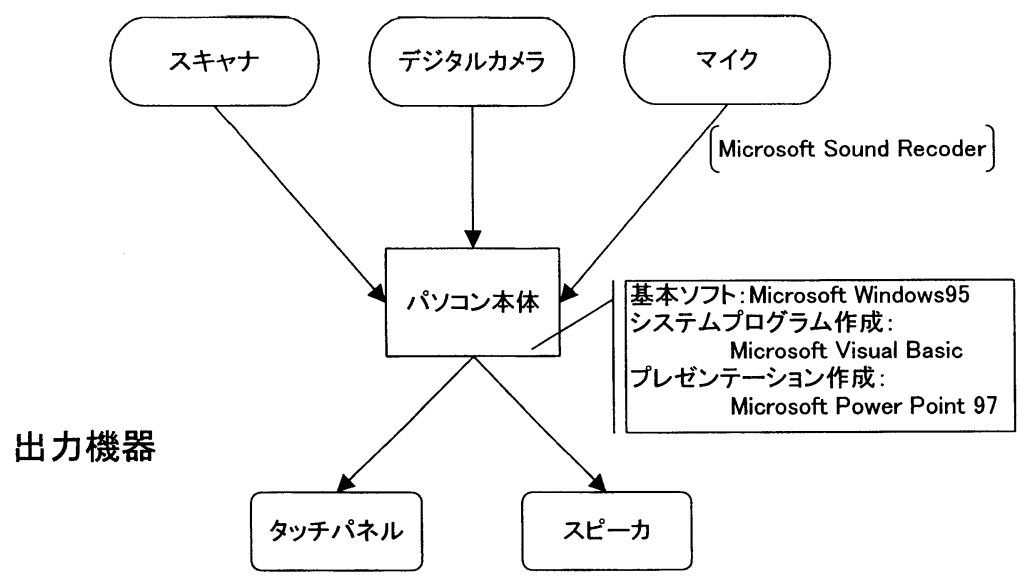

Fig. 1. システム構成図 
Table 1. 作成した医薬品情報提供に対する評価項目

1.タッチパネルで薬の情報を聞いたことがあるか?

2.どの項目の情報を聞いたか?

3. 画面の絵, 写真は理解しやすいか?

4. 画面の文字は読みやすいか?

5. 音声は聞き取りやすいか?

6. 画面操作はわかったか?

7. 内容は理解できたか?

8. パンフレット, 小冊子などを読んだことがあるか？

9. パンフレット等と比較して理解しやすいか?

\section{Fig. 2 に示す.}

初期画面は情報提供内容を選択する形式で操作がわか りやすいように，ボタンのみを大きく配置した。
IAVDIS による情報提供の内容は薬剤部に問い合わせ が多く, また説明が比較的短い内容の事柄を参考にし, 薬荗部製作パンフレットの「坐薬の切り方」,「目薬のさ しかた」,「うがい薬の使い方」，「溶かして使用する薬郕 の使用法」,「原液をつけてお渡しする水薬の服用方 法」，およびメーカー製作パンフレットの「吸入薬の使 い方」,「喘息の患者さんへの注意点」,「痛風とは」を参 考に 8 項目作成した.

各項目の画面数と所要時間は Table 2 に示すよう に，5画面〜14画面により構成され，時間にして40秒〜 146秒間とした。1 画面当りの平均時間は9.3秒である.

プレゼンテーションの内容はスキャナによりパンフ レットのイラストを取り込んだ画面を用いたもの，デジ タルカメラを用いて写真を取り込んだ画面を用いたもの

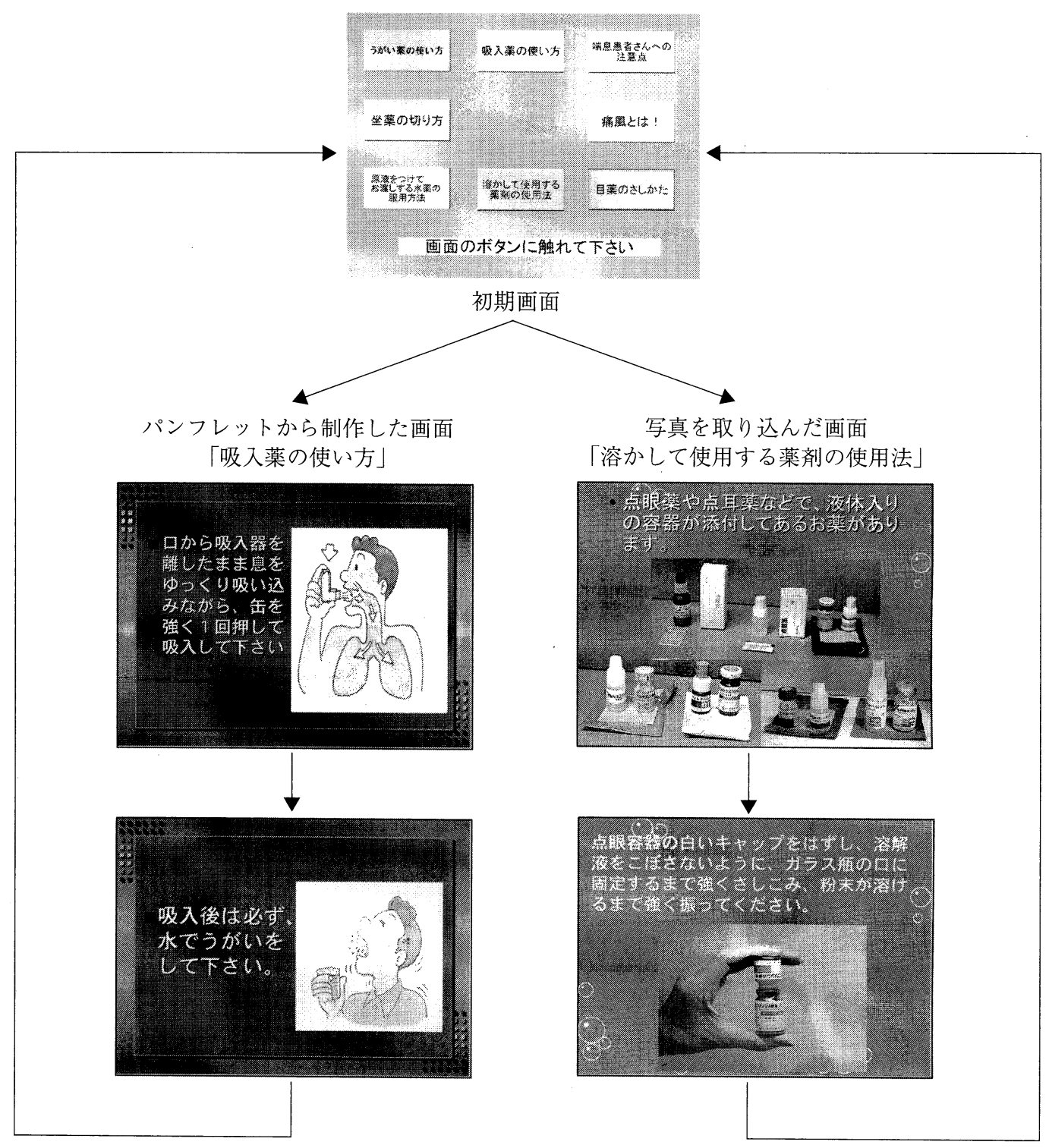

Fig. 2. IAVDIS の初期画面と情報提供画面 
Table 2. 項目別画面数と所要時間

\begin{tabular}{l|c|c}
\hline 項目 & 画面数(枚) & 時間(秒) \\
\hline 坐薬の切り方 & 5 & 40 \\
目薬のさしかた & 7 & 77 \\
うがい薬の使い方 & 7 & 44 \\
溶かして使用する薬剤の使用法 & 14 & 122 \\
原液をつけてお渡しする水薬の服用方法 & 8 & 64 \\
吸入薬の使い方 & 8 & 50 \\
喘息患者さんへの注意点 & 10 & 146 \\
痛風とは & 6 & 63 \\
\hline
\end{tabular}

(Fig. 2) など趣向を凝らし，その上，文字の大きさ， 文字のカラー表示に変化を加え工夫をし，患者の興味を 引き寄せる画面を作成するよう努めた。

\section{2. 情報提供方法の評価}

IAVDIS による情報提供方法に関する自主記入方式に
よる外来患者の調査に対し，男性40名，女性59名，無回 答 6 名の105名の回答を得た。

アンケート結果は Fig. 3 に示すように，30歳代以下 の若年層の回答が多く見られた.

タッチパネルの利用度についての質問に対しては, 「利用したことがある」が $24 \%$ とアンケート回答者中 4 分の 1 がこのシステムを複数回利用している結果を得 た。

構築したIAVDIS による情報提供方法に対しての患者 評価を Fig. 4 に示す.

各設問に対する全体の解答は，画面の絵・写真の理解 度では「理解しやすい」が84\%，文字の読みやすさでは 「読みやすい」が86\%，音声の聞き取りやすさでは「聞 き取りやすい」「普通」を併せて $85 \%$ ，操作方法では「分 かりやすい」，「普通」を併せて $96 \%$ と全体的に $80 \%$ 以上 で高い評価を得た。また，各項目とも年齢層別解析でも 大きな差は見られなかった。

年齢

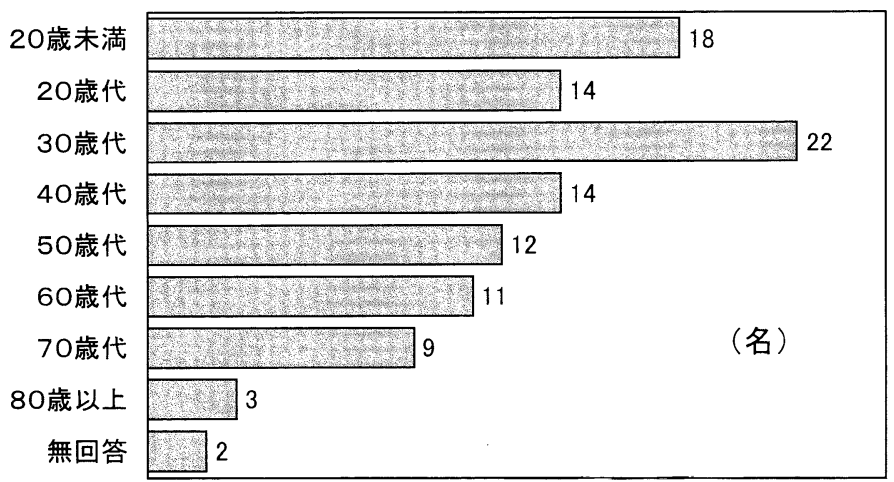

\section{どの項目の情報を聞いたか(複数回答)}

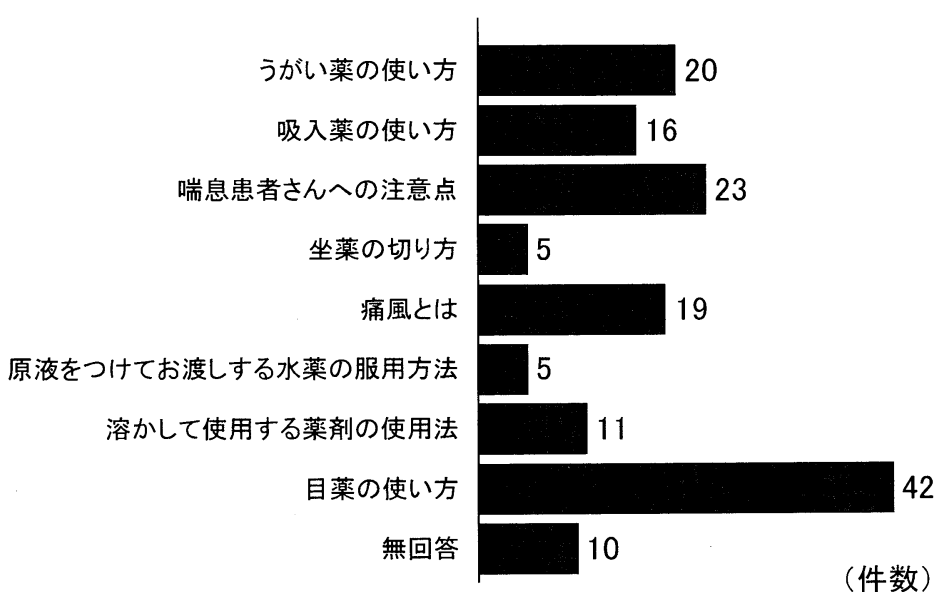

Fig.3.アンケート調査結果 (その 1) 

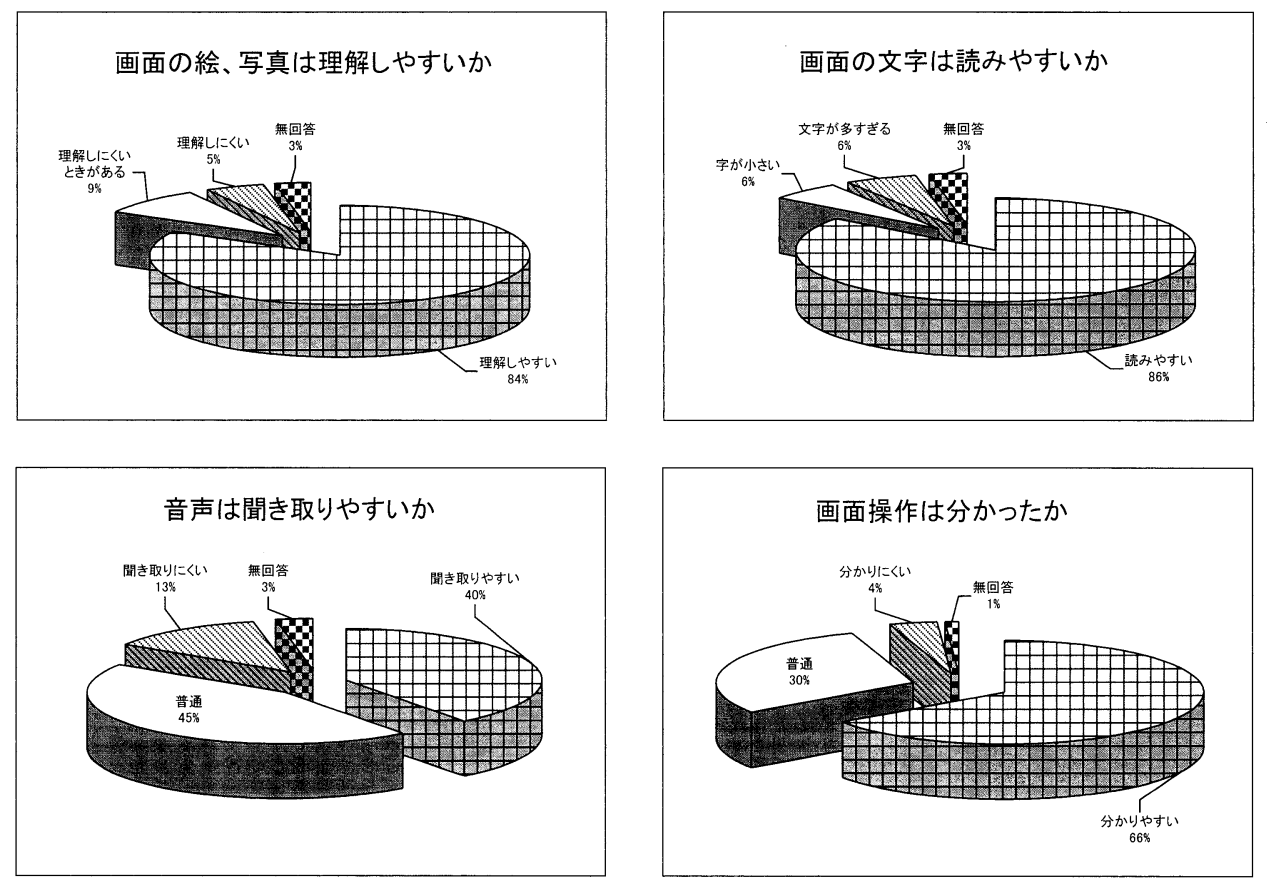

Fig.4. アンケート調査結果 (その 2 )

内容は理解できたか

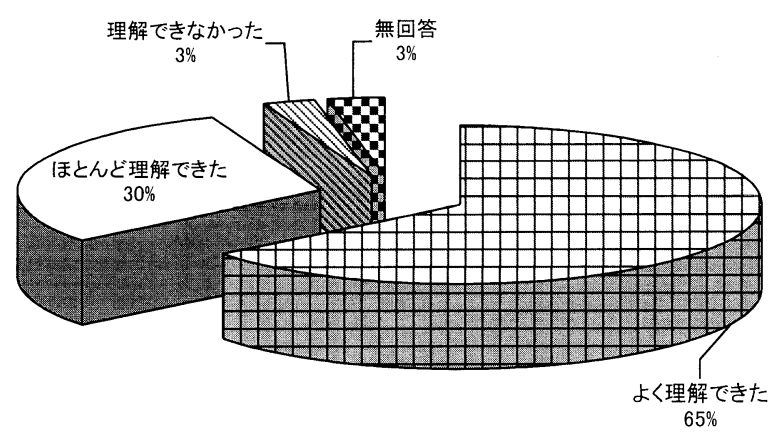

Fig. 5. アンケート調査結果 (その 3 )

Fig. 5 に示すように, 内容の理解度の設問には,「よ く理解できた」65\%，「ほとんど理解できた」30\%と 95\%以上の患者に理解されたと考えられる回答を得た.

また Fig. 6 に示すように「パンフレット，小冊子『匙 かげん』などをご覧になったことがありますか?」の問 いには「ある」61\%，また「ある」と回答した者に対し て「パンフレットと比較して理解しやすいですか」の問 いには「非常に理解しやすい」20\%，「理解しやすい」

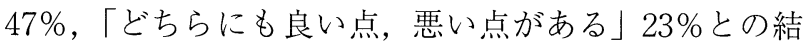
果を得た。

\section{考察}

現在，情報公開に関する規制緩和により，いままで閉 ざされていた多種多用な情報が公開されようとしてい る. 医療現場も例外ではなく，カルテの開示等多くの問 題を抱えながら，情報公開が行われようとしている。ま た，医薬品に関しては，厚生省医薬安全局より平成11年 3 月に医薬品情報提供システムの開始について通知があ り, 同 5 月より医薬品の安全使用推進の目的で医薬品の 添付文書, 副作用等インターネットを介して提供されて いる ${ }^{3)}$.

適正使用の推進を図るため, 平成 9 年 12 月の第 3 次医 療法改定により医療提供者が患者に対し医療の内容につ いて十分説明を行うこと（インフォームドコンセント） が求められており，医療の担い手は医療を提供するに当 たり，適切な説明を行い，医療を受ける者の理解を得る よう努めるものとされた。 また，平成 9 年 4 月の薬剤師 法の改定により薬剂師は患者に対して調剂した医薬品の 適用使用に必要な情報の提供が義務付けられた。多くの 施設では外来患者に対して文書にて処方薬剤情報の提供 を行なってきている4 ${ }^{4}$. しかしながら，医薬品の適正使 用のためには，これらの情報提供を患者サイドで認識, 理解することが不可欠であり，この問題点を解決するた め, 薬剤師は各施設独自の工夫を行い，患者に対する啓 発活動を行っている5).

当病院の外来患者に対する医薬品情報提供方法を 


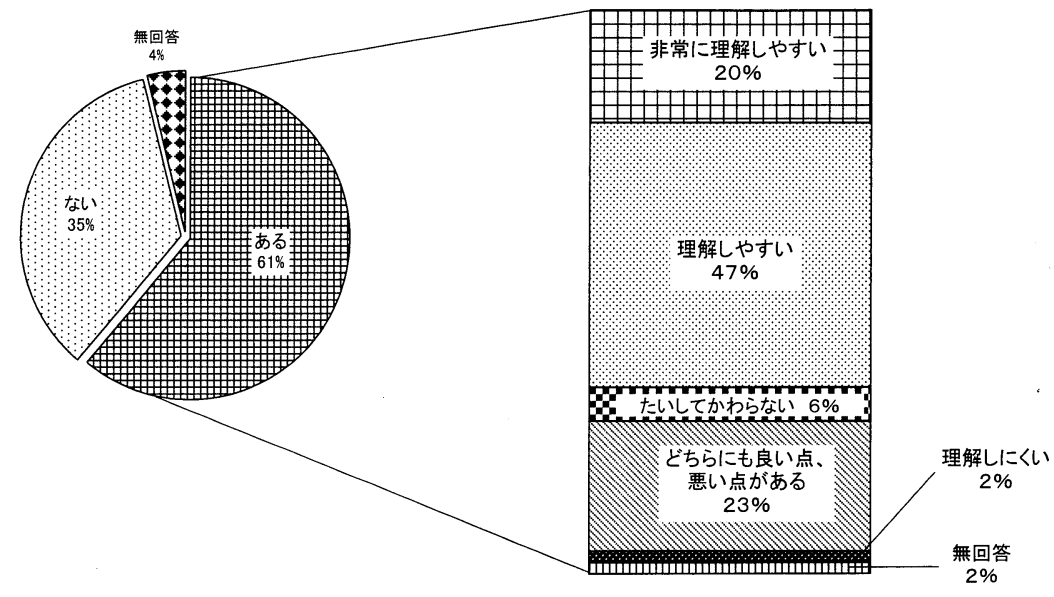

Fig. 6. アンケート調査結果 (その 4 )

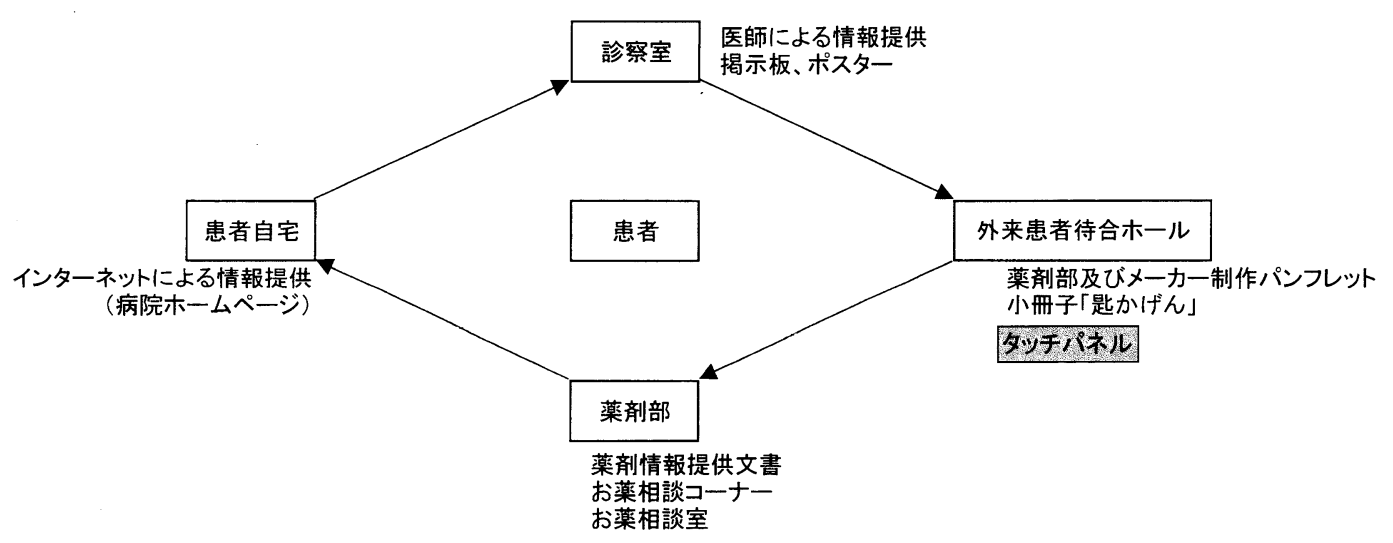

Fig. 7. 外来患者に対する医薬品情報提供方法

Fig. 7 に示す. 当病院では, 患者服薬指導の一貫として 薬剂部およびメーカー製作パンフレット, 薬剤部製作小 冊子「匙かげん」を外来待合ホール内お薬相談コーナー 横に設置し配布を実施してきた。これら印刷物による患 者指導は個々の患者には対応できないが, 医薬品の適切 な使用法, 服用方法など医薬品知識として患者が知る心゙ きことを伝える一手段として考えている。しかしなが ら，これら印刷物による情報の関心の高さは若年層にお いては低く，また患者の医薬品に対する関心度は高い が，薬剤師からの情報提供は十分でないのが現状であ $る^{6)}$.

また，個々の患者への医薬品の情報提供には薬剤師の 数が必要となり, 当院では薬剤師数の増員は困難な状況 にあるため, 個々の患者への医薬品情報説明のための薬 剤師の確保が必要なく, さらに幅広い患者層に医薬品の 適正使用への理解と医薬品に関する関心度を向上させる
情報提供手段の構築が必要と考えた。そこで，外来患者 待合ホールにおいて, 会計および調剂薬の待ち時間を利 用し，また従来からのパンフレットを利用した医薬品情 報提供を参考に情報提供手段の構築を行った。

IAVDIS は実物の医薬品画像やイラストを用いた映 像, 音声録音による器械的でない自然な音響, 操作の簡 便性を重視したタッチパネルを採用した。コンピュータ 画面を用いることにより，従来の印刷物に比べ，画像が 次々に自然に変化するため患者への関心度は高いと思わ れる。

タッチパネルは現在，コンピュータ入力に必要なキー ボードやマウスの煩わしさがない簡便さで多くの公共施 設において利用され, 当病院においても再診療受付機に て採用されている。キーボードやマウスでは, 操作ミス によるシステムの停止, 破損・故障が考えられるが, タッチパネルを導入することにより，操作ミスもなく， 
画面を直接触れれば良いといった簡単な操作のため高齢 者から小児まで，ほとんどの患者に操作できたと考えら れる。

Fig. 6 に示すように, 従来から医薬品情報提供として 行ってきたパンフレット類への関心度は今回の調査でも 高いことが示唆され，また，IAVDISを利用した患者は 従来方法より理解度の向上が計られたと考えられる。

しかしながら，患者サイドでの情報の保存の問題とし て，パソコンによる説明だけではその場限りであるため 不十分であり, 従来からのパンフレット類を併用するこ とにより理解度の持続が得られる。 またコンピュー夕画 面からの情報伝達では情報量の少なさも否めない事実で ある。そこでパンフレット類の内容をさらに充実強化 し，これら 2 者の併用により，患者の薬に対する梁い理 解が得られることと示唆する。

IAVDIS の特徵として，画面変化㧍よび音声による患 者興味の向上，また知りたい情報の選択が患者自身で行 うことができる点であり，また情報内容はデジタルカメ ラ，スキャナ等画像取り込み機器の発達により簡単に薬 剂部で作成することが可能であり，情報内容の更新，追 加は随時に行うことができる点である。

現在, IAVDIS の内容は「医薬品の使用法」,「病態の 説明」，「患者教育」で構成しており，8 項目作成し情報 提供を行っているが，今回の調査により項目の追加希望 が多数寄せられた，特に，医薬品の服用方法，使用法， 副作用，また病態についても意見が寄せられ，改めて患 者の医薬品に対する関心度，薬剤師に対する認識度が高 まっていることが感じられ，情報提供活動の必要性が示
唆された。

今回構築したIAVDIS での情報提供によって外来患者 の興味を引きつけ，医薬品について理解しやすく，患者 自身で知りたい情報を簡単に選択できるシステムが実現 したと考える。

\section{引用文献}

1）入潮佳子，冨田由美，田井浩子，西羅洋子，五十 嵐恵美子，竹内純子，名徳倫明，土師久幸，外来 患者サービスへの試み〜パンフレットコーナーに おける製作パンフレットの役割と考察〜，日病薬 誌，32，405-409(1996).

2）名徳倫明，患者への情報（医薬品情報）提供につ いて，日本病院会雑誌，44，756-767(1997).

3）厚生省医薬安全局，「医薬品情報提供システム」 の開始について（その2), 医薬品等安全性情 報，154，2-3(1999)。

4）名德倫明，青山利人，石坂敏彦，小枝伸行，白川 康文，城野修男，遠嶽秀丸，大阪府下市立病院22 施設に㧈ける外来患者薬剤情報提供の現状調査, 病院薬学, 25, 414-421(1999).

5）入月直子, 清野敏一, 高柳理早, 上村昌子, 折井 孝男，中村幸一，小瀧一，伊賀立二，医薬品の適 正使用を目指した電光表示装置（LED）による静 止・動画像を用いた患者への情報提供とその評 価, 病院薬学, 24, 221-228(1998).

6）名德倫明，西羅洋子，土師久幸，外来患者の求め る情報に関する考察～医薬品に対する意識調査及 び小冊子「匙かげん」の評価〜，日病薬誌， 34，1047-1051(1998). 